\title{
The Crisis of the European Union and Its Impact on Regionalism in Latin America*
}

Kai Lehmann**

\section{Introduction}

The European Union is experiencing one of the worst crises in its history. ${ }^{1}$ The ongoing crisis of, in particular, some member-states in the Eurozone has called into question not only the future development of the single currency and the European economy, but the project of European integration as a whole, as Lehmann (in a forthcoming publication) has argued.

Yet, what has been less explored in the related literature has been the impact of the crisis on the future of other schemes of regional integration. The aim of this paper is to explore how the crisis of the European Union is impacting attempts to establish and develop regional inte-

\footnotetext{
* Article submitted on September 16th, 2013 and approved for publication in November 1st, 2013.

** Kai Lehmann holds a Ph.D. in International Relations from the University of Liverpool. He is a professor at the International Relations Institute of University of São Paulo (USP), São Paulo, Brazil. E-mail: klehmann@usp.br.
}

CONTEXTO INTERNACIONAL Rio de Janeiro, vol. 35, n² 2, julho/dezembro 2013, p. 415-442. 
gration in Latin America which, according to Malamud (2012; 2013), is the region which not only has the most complex web of integrationist schemes in the world but also where the concept of regionalism is in a deep crisis. The question to be answered by this paper, therefore, is whether and to what extent the European crisis has contributed to the apparent crisis of Latin American regionalism. In doing so, the paper will also test the validity of the argument put forward by some, such as Seco (2011), that the European crisis has undermined the possibility of the "European model" being exported to other regions of the world, in our case, South America, now or in, at least, the foreseeable future, as has occurred in the past.

Based on a review of the existing literature and interviews with key players from the Brazilian government, the European Union and Brazilian industry, it will be argued that the crisis which the European Union is currently experiencing may be a contributing factor to the problems faced by South American regionalist schemes, but it has not been - based on the research done so far - the principal factor. The main factors, it will be shown, can be found in the region itself and in the particular circumstances in which regionalism in South America occurs. ${ }^{2}$

The paper will clarify what are the key factors for the current problems of South American regionalism, what these problems mean in terms of political action, and what can be done to overcome these problems, where the European Union and its current problems can, in fact, play some part. Finally, areas for further research will be outlined.

\section{The Historical Context: The European Union as a Model for Integration in South America}

As shown by Williamson (2009), there is a long-standing and, in many ways, obvious political and economic connection between 
South America and Europe. Two of the European Union's members were the principal colonizers of South America. Economically, the European market has long been one of the most important, alongside the United States, markets for South American products. ${ }^{3}$

The importance of the European market for South America has a significant impact on how the European Union is seen in the region, both in economic, political and ideological terms. For instance, according to one minister in the Brazilian foreign office (Itamaraty), "in terms of a common market, the European Union is a [great example]. How this group of so many countries with [so many differences] managed to create a common market which actually works is something very special, the only one [of its kind] which exists". 4 A senior representative of Brazil industry agrees: "The European Union [for us] is seen as something desirable, it is [...] a premium market". 5

The economic importance of the European Union for the region and the generally held view that the European Union and its single market have been a success - has also had a significant political impact. According to Malamud and Gardini (2012, p. 121), "the shadow projected by the European model [has] imbued into most regional leaders the idea that anything short of integration is a political failure [...]." This, almost inevitably, led to attempts to "copy" the European experience, bearing in mind that "the marketplace of ideas regarding it is substantially limited to one successful source, the EU" (MALAMUD, 2012, p. 181).

This ideological component grew significantly in importance on both the South American and the European sides as a tool for promoting regional integration. According to Ruiz (2006, p. 14), the liberal model promoted by the European Union, especially since the end of the Cold War, "was the ideological basis of the new Latin American regionalism [...]". The EU itself made the promotion of this kind of regionalism part of its "governance package" and "inter-regiona- 
lism" one of the "foundations of its foreign policy" (BÖRZEL; RISSE, 2009, p. 10). Picard et al. (2009, p. 7) agree, arguing that the EU "presents itself to the world as an example of integration with positive social effects for its peoples: a democratically and socially meaningful integration."

During the 1990s, therefore, the European Union became "both a model and a partner for a new wave of regional organizations [in South America]" (MALAMUD, 2013, p. 1). It did so in both economic and political terms, promoting the opening up of markets, as well as promoting democracy, respect for human rights etc. In fact, this policy was in no way restricted to that particular region becoming, instead, a global strategy, as Cameron (2010) has shown. The EU itself has stated that its aim was "to share the European experience with interested parties", as the Commission of the European Union (2004) put it.

Yet, it is also worth pointing out that some commentators have always argued that the European Union embarked on this kind of "mission" for far more than altruistic reasons. Economically, there are obvious benefits for the European Union to promote the opening up of emerging markets like those of South America, with its growing consumer base. At the same time, politically, the EU "promotes similar entities to itself as a way to legitimize itself” (SECO, 2011, p. 3). In other words, the argument is that the European Union does not promote regionalism for purely normative reasons but does so, also, out of clearly-defined self-interest.

Without doubt, the EU has, especially since the end of the Cold War, tried to promote its political role and underlined its success in creating and maintaining peace and stability both among its member states and within its immediate neighborhood as one of its principal achievements, as Dinan (2004), amongst others, has argued. In fact, as Manners (2008) has shown, the European Union has always had a 
strong moral and ethical dimension during its entire existence. Significantly, this role of the EU was explicitly recognized when the organization received the 2012 Nobel Peace Prize, recognition which undoubtedly was useful to it in terms of promoting and preserving its political legitimacy, as Lehmann (2012) has argued.

Thus, there seems to be no doubt that the European Union has - at least during parts of its history - both served - and promoted itself - as a model and an inspiration for integration, be it in South America or elsewhere. Looking specifically at South America, however, this leads to two critical questions: Has it worked and has the present crisis of the European Union had any kind of impact on regionalism in South America?

\section{Model Europe and the Crisis of Regionalism in South America (I): Structural Factors}

There is common agreement between commentators and political leaders that the current crisis of the European Union has had some impact on its ability to "sell" its model to other regions as one to follow. As Cameron (2010, p. 4) states, "[t]here is no doubt that the current crisis [of the EU] has affected the European Union as a model for regional integration." Ruiz (2006, p. 14) agrees but goes further, arguing that the model which the EU has been promoting - basically trade liberalization, democracy etc. - is "currently in crisis in many countries of [South America]." One senior EU diplomat interviewed for this research and currently based in the region admitted that, in view of the crisis, the EU"s "impact outside Brussels is rather limited". 6 Another one stated that the EU historically was "not very good at selling itself" and that the current crisis had made that problem even worse. $^{7}$ 
Critically, this crisis of the "European model" comes at a time when South American regionalism is also passing through what many commentators have called a crisis. For instance, in relation to perhaps the best-known of South American integration schemes, MERCOSUL, one analyst remarked to the author that the organization "only still exists because the costs of keeping it going are lower than the costs of closing it down". ${ }^{8}$ Malamud and Gardini (2012) asked whether regionalism in South America "has peaked", whilst, in a separate article, Malamud (2012, p. 178) observed that

[...] 20 years after its foundation, the common market of the south, MERCOSUR, has failed to meet its declared goals. Far from being a common market, and not yet a customs union, - or even a fully-fledged free trade zone -, it has neither deepened nor enlarged. Remarkably, all other regionalist projects in Latin America fare even worse.

Other commentators have made similar observations with Dabène (2009, p. 3) arguing that regionalism in South America has been "unstable and, according to 'Europeanized' common sense, unsuccessful." One diplomat of the European Union went further, stating that, both in relation to South America in particular and more generally, "multilateralism is in deep trouble" with "negative consequences" for schemes of regional integration. ${ }^{9}$

Bearing all of this in mind, it is important to ask whether there is a connection between the current crisis of "model Europe" and the current crisis of regionalism in South America.

Why, then, is there a crisis of South American regionalism? One can start by looking at some of the strategic problems in the region.

The first problem encountered when discussing South American regionalism are the basic disagreements between countries in the regi- 
The Crisis of the European Union and Its Impact on Regionalism in Latin America

on about what regionalism is actually for. In the economic sphere, for much of the first wave of regionalism, the aim was one of protecting a particular region from outside competition. This so-called "closed regionalism" aimed at insulating regions from outside competition, pursuing, for instance, strategies of import-substitution as a way of ensuring economic growth and self-sustainability. ${ }^{10}$ This approach changed during the second wave from the 1990s onwards, when regionalism was seen as a way of promoting exports and opening up other markets. Following the example of the European Single Market Project, both MERCOSUL and UNASUL formulated similar aims, as Malamud (2012; 2013) has shown.

Yet, this change towards "open regionalism" of the "European type" has never been uncontested among the countries in the region. As commentators such as Maihold (2009) have pointed out, protectionist measures from one government or other are still common and national attitudes towards free regional trade change frequently, depending often on the whims of populist presidents responding to domestic situations or pressures. In fact, all those interviewed for this research identified this as a key problem for South American regionalism.

This general problem can be exemplified by looking at how it is specifically manifest at the present time. According to the EU official interviewed, the tendency towards populism in the region has always been a problem and, currently, in this respect, "Argentina is a big worry", 11 a claim independently made also by the minister of the Brazilian government and the representative of Brazilian industry.

Linked to this are profound ideological differences between the countries of the region which, depending on one's point of view, make the strengthening of regionalism, at best, very difficult and, at worst, impossible. As Seco (2011, p. 12) has argued - in this case specifically in relation to the Andean Community - these differences 
mean that few shared interests exist between member states, political disputes are common whilst a lack of trust between member states leads to weak political institutions and the non-implementation of decisions that have been made. Such problems, according to the minister, are commonplace, also because of the fact that "policies oscillate a lot [from government to government and over time] in [some states]."12

Finally in this respect, and linked to the above, it is also crucial that regionalism in South America has, generally speaking, had very little to do with attempts at "region building". For instance, there are profound differences between South American countries about their relationship to the region termed "Latin America". Whilst this is apparently clear to outside observers, and indeed to several South American countries, it has, for centuries, had little resonance in Brazil, as Bethell (2010) has shown, pointing to a number of cultural and social differences, as well as a significantly different strategic outlook in political terms.

The consequence of these issues being unresolved is that there are few - or no-shared objectives between the countries of the region in relation to regionalism. As Phillips and Prieto (2011) have shown, the proliferation of regional schemes in the region, therefore, does not represent strength but exposes the weakness of South American regionalism. It is a response to a particular problem at a particular time rather than the result of longer-term strategic thinking, leading to "[o]verlaping regionalism [but] no integration", as Malamud (2013) put it.

One can illustrate these problems perfectly by looking at one of Brazil's more ambitious plans, the establishment of UNASUL - the union of South American states - developed by the then Brazilian president, Lula. Created in 2008, it brings together 12 Latin American countries and aims, amongst other things, to establish a common 
market amongst its member states, enhance cooperation on matters of defense policy, develop a common approach to South American infrastructure projects as well as other issues, such as health policy. ${ }^{13}$

Yet, despite these often grandiose aims, the overall impact of UNASUL has been limited. Apart from disputes about specific issues, such as the plan to establish American military bases in Colombia, there have been far broader disagreements about the overall objectives of UNASUL. For Brazil's foreign ministry, Itamaraty, the objectives of UNASUL are the "strengthening of political dialogue between member states and the deepening of regional integration", as The Economist (LULA..., 2009) has stated. Yet, what that precisely means in practice has been a source of continuous disagreement and debate among the member states. For instance, while Chile has been quite specific in stating that it sees UNASUL primarily as an instrument for strengthening social inclusion, as well as furthering infrastructure development and ensuring a continuous energy supply, Bolivia sees in UNASUL a chance to create a "union of peoples", whatever that may mean in practice. While some see South American integration as a pragmatic way of furthering economic and political interests, others, such as former Venezuelan president Hugo Chavez, talked about the organization in ideological terms (LULA..., 2009).

In many ways, this underlines the problem of a lack of trust between the region's governments, a fact crystallized by looking in more detail at the current state of the other major integration scheme launched by Brazil, MERCOSUL and its recent decision to admit Venezuela as a full member. Having initially applied to join in 2006, Venezuela's accession to the block was ratified by Argentina, Brazil and Uruguay but was held up by Paraguay. Yet, the suspension of Paraguay in 2012 for supposedly breaching the "democracy clause" of MERCOSUL in the impeachment process against the then president Fernando Lugo, allowed for the other members to wave through Venezuela's 
entry. This has led Paraguay to threaten legal proceedings against the move once its suspension is lifted. ${ }^{14}$

Leaving aside the legality or otherwise of the process, the whole episode illustrates that even 20 years of integration efforts have not led to a relationship of trust between South America's political leaders. However, such political trust is a critical and key foundation for any institutional progress, since integration efforts in the region are almost exclusively dependent on progress agreed between presidents, "presidentialism" being the principal modus operandi for Latin America's regional groupings, lacking, as they do, a strong, resilient and reasonably autonomous institutional and political structure. ${ }^{15}$

The above discussion and examples do not even begin to touch on some of the other key strategic issues around which South American regionalism has been based but about which little agreement exists. One such issue is the relationship between the region and its powerful northern neighbor, the United States.

The United States has had a long-standing political interest in the region, as exemplified by the Monroe Doctrine. ${ }^{16}$ That the U.S. should have an important role is hardly surprising, bearing in mind its political and economic importance to the region. Yet, this involvement has, over time, led to widely different reactions from its southern neighbors, both inspiring and hindering regional integration projects. In simple terms, the relationship with the United States has been one of the key wedge issues whenever Latin American countries have thought about and constructed regional integration. For some, regional integration has been used as an instrument to insulate Latin America from the influence of the United States, seeing it as one way of gaining leverage over the continental superpower and, therefore, rescuing or recovering some of its own autonomy and independence. For other countries over time, integration has been seen as a way of ensuring American influence, binding the participant countries into 
the American bloc and therefore enjoying the ensuing advantages, for instance in terms of security but also in terms of commerce. Often these competing aims of objectives in relation to North America have led to severe tension within and between Latin American countries. ${ }^{17}$

To complicate matters further, the positions of Latin American countries in relation to the United States have changed over time, with Venezuela once again providing an excellent example. From being one of the most reliable U.S. allies during the Cold War, the country today represents the most strident opponent of U.S. influence, seeing regionalism precisely as one instrument to keep the United States at bay. Such strident positions are in stark contrast with the far more pragmatic approaches adopted by countries such as Brazil or Chile. ${ }^{18}$

Looking at the above, it seems difficult to argue that it is the crisis of the European Union which has led to the current state of affairs in South American regionalism. In simple terms, even if one took away the EU crisis, the factors mentioned above would still exist, as the minister interviewed for this article admitted, though in a slightly different way: "[Our context] is very different to that of Europe [so that] the European Union model [would not be] very easy to copy". 19

However, this is not to say that there are no connections or similarities between the current EU crisis and that faced by South American regional institutions. In very basic terms, what the above shows in relation to South America and what Lehmann (in a forthcoming publication) has shown in relation to the European Union, is that neither is currently able to act coherently because neither knows exactly for what they are undertaking regional integration. Neither, in other words, has an answer to the question what does regionalism actually mean, whether in political or in economic terms. In fact, one senior EU official argued that it was necessary, first, to solve the current crisis, and then "define our [new] strategic objectives", arguing essentially that the two things were separate. ${ }^{20}$ In defining these problems as 
separate and sequential, the official actually comes close to one of the problems identified by the representative of Brazilian industry for South American regionalism already mentioned above: lack of strategic thinking: "[The region] thinks short-term", which also explains the proliferation of many regionalist schemes. ${ }^{21}$

These strategic problems are compounded by a number of specific contemporary factors which will now be explored.

\section{Model Europe and the Crisis of Regionalism in South America (II): Contemporary Factors}

It would be a mistake to look at the strategic factors mentioned above in isolation. As I hope to show now, in many ways, these factors are shaped by - and sustained by - some of the key contemporary developments in the region.

The first of these developments is the relatively positive economic situation in most, though by no means all, states in the region. In particular, this trend can be observed in the region's most powerful country, Brazil, which has enjoyed more than a decade of almost continuous economic growth.

This has had three significant consequences: First, a change in relation to the perceived benefits of regionalism in general which, in turn, meant a decline in the importance of the EU as a model for, especially, economic integration. Second, a perception - and a push for increased political influence on the global stage and, linked to this, thirdly, growing discord between regional governments, especially between Brazil and some of its partners.

In relation to the first aspect, the relative economic success of the region over recent years - even in the absence of highly-developed re- 
gional schemes - has led to a questioning of the necessity of such schemes. As Del Arenal (2009) has pointed out, the lack of a regional economic crisis has meant that there has been a lack of urgency in relation to the furthering of regionalism. As such, the importance of the already existing blocs naturally diminishes.

This is not to say, however, that there have been no regional crises and discord, even in the economic sphere. For instance, whilst countries like Brazil or Chile have powered ahead economically until recently, others, such as Venezuela or Argentina have, in fact, faced economic stagnation or decline. As a consequence, other countries and regions have increasingly focused their attention on those "successful" countries, to the detriment of truly regional strategies since, at least according to some, "it is clear that the priority for Europe is its own economic interest and not regional integration" (PICARD et al. 2009, p. 19).

There is thus a twin and self-reinforcing process of economic and political divergence within and between the countries of the region, with significant consequences for the relationships between them. This can be illustrated by looking a little more closely at Argentina and Brazil.

All those interviewed for this research pointed out that Argentina currently represents a serious problem. Beset by a weak economy and high inflation, the country has actively sought to shield its economy from outside influences, with significant consequences for regional integration. As the representative of Brazilian industry put it, there are currently "ideological differences [which] make things difficult" in terms of regionalism. Importantly, though, these ideological divergences are often the result "of purely internal factors", according to the interviewee. ${ }^{22}$ The impact of this divergence is not only practical, but also political in that "it sends out a bad image" with respect to being able to "do business in and with the region". 23 
Yet, the "internal factors" referred to above are crucial to understanding one of the key factors that is currently blocking progress towards more regional integration. In very simplified terms, according to all interviewees, Argentina cannot be seen to cede more ground to Brazil at a time when Brazil is actively seeking a regional leadership role and when, there is certainly the perception of increased political influence, or, in the words of Michael Shifter (2012), "growing self-confidence and prominence in global affairs" in Brazil. This growing self-confidence has had significant political consequences. Apart from continuing to push for a permanent seat in the UN Security Council, the country has played a prominent role within the G20 Group, has increased its participation in UN peacekeeping missions, particularly in Haiti, has had a leading role in negotiations within the context of the WTO, and has been a prominent proponent of the BRICS group of countries of emerging economies.

However, noticeably, the instruments through which the aim of a larger political role is being pursued have changed. From being one of the key promoters of regionalism, recently the country has followed a more unilateral path, as evidenced by its reaction to the military coup in Honduras in 2009, when the government allowed deposed President Zelaya to stay in its embassy. Lula's successor, Rousseff, has generally not been a great promoter of regionalism, but rather has charted a more independent course, as Rothkopf (2012) has shown. Regional mechanisms are being ignored in favor of individual solutions, a process aided by the extremely weak - often non-existent - institutional structures of the overlapping regional institutions created to deal with just such issues. ${ }^{24}$

Ironically, the weakness of the regional structures is reinforced by the growing instability of some countries. In Venezuela, for instance, the death of President Chavez and the subsequent disputed election has added to the uncertainty already stoked by tensions over the government's interpretation of the constitution in relation to presidential 
succession, with accusations being made that certain key constitutional provisions are simply being ignored in order to ensure the continuation of "Chavistas" in power. Add to this, serious economic problems such as rampant inflation, and the scenario which presents itself is one of growing instability. ${ }^{25}$

Taking into account all these issues, it perhaps should come as little surprise that there is growing political discord between the countries in the region. This has already been illustrated above by briefly looking at the resistance in Argentina to further regional integration so as to - amongst other things - not cede more political influence to Brazil. Yet, it would be unfair to single out Argentina as the only country which is uncomfortable with Brazil's rise. Brazil's rise, and subsequent increasingly bi-lateral approach to foreign policy and economics, "has been the cause of regional dispute", according to Picard et al. (2009, p. 19, my emphasis). Malamud (2013, p. 57) agrees, arguing that "it is not hard to discern spreading resentment amongst Brazil's South American neighbors - a natural product of increasingly unequal power manifest in the continent".

This perception has only accelerated the fragmentation of South American regionalism. As shown above, such fragmentation shows itself primarily through the proliferation of often overlapping schemes of regionalism but is also shown by the myriad of justifications used by countries to explain their participation in often various regionalist schemes.

This process can be perfectly illustrated by looking at MERCOSUL. As Malamud (2012, p. 182) has summarized:

For Brazil the bloc has become an instrument to administer its relations with Argentina, long considered the only country important for Brazil and to which Brazil is also important. Symmetrically, Mercosur's main function for Argentina is now to bind Brazil and prevent it 
from making unilateral decisions or going global alone. For Paraguay Mercosur is not an option but a doom (paraphrasing Celso Lafer, who once said that, for Brazil, the FTAA was an option while Mercosur was destiny): it is unavoidable - as exclusion costs would be higher than pennanence - though not necessarily good. In the case of Uruguay, exclusion costs and political inertia explain the decision to stay in the bloc, although in this case the ruling coalition's ideology also plays a role.

However, even within the context of this one organization, considerations are currently shifting again, both in response to the factors already outlined above, and in response to the weakness of the organizations themselves: Paraguay, for instance, recently indicated that it was in no hurry to re-join MERCOSUL, after having been invited to do so. ${ }^{26}$

There is thusconsiderable tension which undermines the process of regionalism in South America: On the one hand, there is a growing sense of confidence within the region, a belief that the region is finally shaking off its culture of dependency and deference, be it to the United States or "the West" in general. This growing confidence has led to a re-evaluation of the merits or otherwise of regional integration, with the general conclusion being that "regionalism is out, sovereignty is back in", as Malamud (2012) put it.

On the other hand, many of the problems which have plagued the region over the decades have still not been resolved, whether strategic in nature or particular to a specific country, leading some to argue that the region is "not ready for primetime" (CASTAÑEDA, 2010). As such, many of the issues that gave rise to regional initiatives over the years are still present, but the interpretation made by governments about them and how best to tackle them have changed. The context in which these issues are seen and addressed has changed and acquired different dynamics. 
The result of these changing dynamics has been a change of emphasis in terms of what type of regionalism is occurring in South America. Moving away from grand projects of integration, the region has turned towards what Gardini recently termed at a seminar "modular regionalism", a "mix and match" approach to dealing with particular issues which require cooperation or integration in response to specific problems. In fact, in relation to the European Union this has meant, according to Gardini (2013), a "strong emphasis on business links" since, as already shown, the EU continues to be seen as a "prime market" for South American countries. Another example of this "modular approach" has been the creation of the UNASUL Health Council.

Within these dynamics, what is the role of the European Union as it passes through its current crisis?

\section{The European Union, Its Crisis and the New Dynamics of South American Regionalism}

In the text up to now I hope to have shown two things: First, it is clear that the European Union has been seen as an example for - and been admired as such - South American regionalism. Yet, historically, none of the numerous regionalist schemes in South America have come close to emulating the EU either economically or politically. In fact, the vast majority of these schemes are not even regional in scope, instead representing overlapping sub-regional bodies with no attempt being made at "region-building". Thus, there has been a permanent discrepancy between rhetorical adherence to the EU, as an example to be followed, and what has actually been achieved in practice. 
Secondly, it has also been shown that, even in this very limited sense, the attractiveness of "model Europe" has suffered as a result of the crisis which the European Union is currently experiencing. However, the second part of this text has made clear that one cannot make a direct link between the current problems of the European Union and the crisis of South American regionalism. To do so would ignore the multiple issues that need to be resolved between the countries of the region quite independently of the involvement or otherwise of the European Union. Rather, one could conclude, as did the EU official interviewed, that the current EU crisis and the current crisis of South American regionalism are an expression of a much deeper crisis of multilateralism and regionalism in general, as was already stated above.

However, this is not to say that the EU has not committed serious errors in its dealings with South America as a region which - whilst perhaps not directly contributing to the current crisis of regionalism in that region - have certainly made it much more difficult for the European Union to have a positive influence on the strengthening of existing (or new) regionalist schemes.

The main criticism labeled at the EU is that it has simply not responded quickly or profoundly enough to the changing dynamics outlined above or, where it has, for instance in focusing more on bilateral deals, that it has done so without explaining this to other regional partners or, indeed, without the existence of a broader context and coherent agenda within which such a change of approach could be understood and explained.

In relation to the first point, Börzel and Risse (2009, p. 12) have argued that "the EU appears to have developed a 'one-size-fits-all' approach to promoting regional integration on a region-to-region basis in South America." Del Arenal (2009, p. 4) complains that "since the mid-1990s, despite the decisive changes that have taken place, the 
EU has not modified its strategy for relations with Latin America significantly". Freres and Sanahuja (2006) simply attest that the current EU approach is inappropriate for serving either Latin American interests or those of the EU. In fact, this has been an emerging theme in the literature, with some arguing that the EU "lacks a strategy adapted to the new realities" which can be explained by the fact that, in many ways, Latin America is no longer considered a major development priority for the EU and that, therefore, there is mutual disinterest between the two parties (DEL ARENAL, 2009, p. 17).

However, such criticism may be a little bit unfair in its sweeping nature. As briefly touched upon above, the EU has adjusted its approach, doing far less in terms of dealing with the multiple organizations that exist and focusing far more on specific bi-lateral relations it considers to be of most value, Brazil being the prime example, as Saraiva (2013) has shown.

This change of focus, where accepted as fact, has drawn a different type of criticism, namely the failure of the EU to explain its objectives and properly engage with the various stakeholders in the region. As Picard et al. (2009) have shown in some detail, the change in tactics by the EU has caused significant tensions both within the region (between those negotiating bilaterally with the EU and those that do not) and between the EU and some countries in the region. This, in turn, has only made the resolution of the particular South American crisis of regionalism more difficult.

This, in turn, leads us back to a much broader problem that the EU has been facing (but not resolving) for some time and which, as Lehmann (in a forthcoming publication) has shown, has directly contributed to the particular economic and fiscal crisis which it is experiencing: the lack of internal leadership and a subsequent failure to address the big, strategic issues it faces. As Bittner (2010) has put it, the EU does "big things too small and small things too big", and it is here that we can 
find the "common ground" between the two regions and the two crises.

As shown throughout this text, the crisis of South American regionalism is the result of a variety of interdependent factors across several levels of analysis which have led to a pattern of multiple, overlapping, sub-regional and duplicating schemes of regionalism which lack an overarching theme, a "container" that can hold the project together. The same can be said about the current state of the European Union which, even according to some of its most senior officials, does not have an overall objective at the moment, other than "resolving the crisis", as one representative of the European Council put it. $^{27}$ The EU is reactive rather than proactive, just as countries in South America are in relation to regionalism. As such, rather than creating problems in relation to regionalism either in Europe or South America, the European crisis reinforces existing problems and tendencies.

Bearing in mind all of these factors, what can the European Union actually do and what can its impact be on regionalism in South Ameri$\mathrm{ca}$ ?

Apart from having a clear idea about its strategic aims, there should first be an acknowledgement on the part of the EU of its own limits and problems, and a related adjustment in expectations. Whatever type of regionalism emerges in South America over time will not be like the "European type". In fact, the current tendency towards "modular regionalism" mentioned above only reinforces this point. Equally, as the current crisis shows, that European type perhaps can and should - no longer be seen as the "ideal type". In other words, the EU should both adjust its expectations and show some humility in the face of its own difficulties. In many ways the best the EU can hope for is to incentivize changes of behavior from the key actors, encourage experimentation in engagement through proposals which these ac- 
tors may consider "good enough to try", as one observer put it to the author, without, however, having any certainty of the outcome, both in terms of the structures and interactions that may emerge and the impact these may have on the problems being confronted.

Second, the focus of regionalism in South America is - and perhaps has to be - different from that in Europe. As Seco (2011, p. 11) has shown in relation to the EU's efforts to promote region building in the Andes, "projects with a more practical character have fared better" than the promotion of grandiose schemes of political integration. Since experience seems to have shown conclusively that the EU model cannot - and should not - be exported in its entirety to other regions, as Goldirova (2007) has argued, a move away from grand schemes to practical - and realizable - projects would not only seem to be the sensible thing to do but would actually serve the broader objective stated above: incentivizing regional cooperation as a way of solving practical problems. Regionalism therefore could become something more "modular", but with clearer practical benefits.

Thirdly, and particularly bearing in mind its own problems, the EU ought to see its engagement in the region as a mutual learning process. Reading the programs and schemes the EU has for Latin America there seems remarkably little knowledge about the highly complex developments and interactions going on within the region and between it and other regions. As such, it would be very difficult for the EU to respond to the particularities of both the region and each country - each conflict - within it. The Latin American region is far more complex - in a descriptive as well as a conceptual sense - than the EU is at least publicly willing to admit. However, knowing what and who one is dealing with is critical. From the country and regional strategies that exist, there seems to me to be insufficient knowledge of the differences that exist in the region across time and space and the differences these make in terms of impacting on policy effectiveness. $^{28}$ 
None of the above, however, will have any impact if there is, at the same time, no willingness on the part of the countries in the region to engage both with the EU and, more critically, with each other. As shown, there is a distinct lack of confidence between political leaders in South America and not even the merest consensus about what (sub-)regionalism is for. This crisis far pre-dates the European crisis and needs to be resolved within the region itself. The influence the EU can have over such a process is, it would seem to me, very limited at the best of times. Acknowledging such fact would be a first step towards trying to influence any emerging developments.

\section{Conclusions}

The principal argument presented in this article has been that the crisis of the European Union has contributed - but did not cause - a parallel crisis of regionalism in South America. Whilst it is true to say that the problems of the EU have made the organization less attractive as a "model" to be followed in South America, it has also been shown that local regionalism was already facing formidable problems before the onset of this crisis, problems which have deepened since.

Ironically, the problems confronted by both regions - whilst very different in their particular manifestations - are actually very similar in their strategic causes. In both regions, the lack of strategic leadership and agreement concerning the overall objectives of regionalism has led to a situation where the necessary strategic decisions needed to move the relevant regional schemes forward cannot be made.

Critically, however, the changing political and economic dynamics of the South American region mean that the European Union has very little influence over the direction regionalism can and will take in the region. In fact, the major impact of its own crisis has been the fact that this influence has diminished still further. As such, the major 


\section{The Crisis of the European Union and Its}

Impact on Regionalism in Latin America

impetus for re-starting regionalism has to come from the South American countries themselves, something that looks unlikely at the moment due to a combination of both unresolved structural and strategic questions as well as a number of particular current issues that some countries in South America - as well as the region as a whole - are confronting, over all of which the European Union would seem to have very little sway. As such, the best that the EU can currently do is resolve its own problems, incentivize, engage, learn and adapt to the particular situation it confronts in South America.

Taken together, it seems that both regions are facing a general crisis of regionalism which merely manifests itself in different forms over time.

\section{Notes}

1. As one senior EU diplomat admitted in an interview with the author.

2. Time - and financial constraints have meant that interviews have so far been possible only with Brazilian - or Brazil based - players. It is hoped that, as this research is developed, a much broader empirical base can be developed.

3. For the 2012 trade figures, see: <http://www.wto.org/english/res_e/statis_ e/its2012_e/its2012_e.pdf>.

4. Interview with minister, June 2013.

5. Interview with senior representative of Brazilian industry in São Paulo, June 2013.

6. Interview, June 2013.

7. Comment made to author during a seminar in 2012.

8. Remark made to the author during a seminar in 2012 .

9. Interview, June 2013. 
10. For an overview of this first phase of South American regionalism, see Nogués and Quintanilla (1994).

11. Interview, June 2013.

12. Interview, June 2013.

13. See, for instance, Almeida (2009).

14. See Exame (PARAGUAI..., 2012).

15. See, for instance, Cheibub et al. (2011).

16. See, for instance, Williamson (2009).

17. For an overview, see Smith (2007).

18. For one take on the ongoing changes, see Crandall (2011).

19. Interview, June 2013.

20. Remark made to the author during a seminar in 2012.

21. Interview, June 2013.

22. Interview, June 2013.

23. Interview, June 2013.

24. See Malamud (2012).

25. See The Economist (NOW..., 2013).

26. See Correio do Povo (CARTES..., 2013).

27. Remark made to author during a seminar in 2012.

28. See European Union (2009).

\section{References}

ALMEIDA, Paulo Roberto de. Lula's Foreign Policy: Regional and Global Strategies. In: LOVE, J. L.; BEAR, W. (Ed.). Brazil under Lula: Economy, 
Politics, and Society under the Worker-President. New York: Palgrave-Macmillan, 2009.

BETHELL, Leslie. Brazil and Latin America. Journal of Latin American Studies, v. 42, n. 3, p. 457-485, 2010.

BITTNER, Jochen. So nicht, Europa. Die drei grossen Fehler der EU. München: DTV Premium, 2010.

BÖRZEL, Tanja; RISSE, Thomas. Diffusing (Inter-)Regionalism: The EU as a Model of Regional Integration. In: KFG Working Paper No. 7, September 2009. Berlin: Freie Universität, 2009.

CAMERON, Fraser. The European Union as a Model for Regional Integration. CFR Working Paper September 2010. New York: Council of Foreign Relations, 2010.

CARTES assume Paraguai com posição firme sobre Mercosul. Correio do Povo, August 15th, 2013. Available at: <http://www.correiodopovo.com.br/Noticias/?Noticia=505441>. Accessed on: December 2013.

CASTAÑEDA, Jorge G. Not Ready for Prime Time - Why Including Emerging Powers at the Helm would hurt Global Governance. Foreign Affairs, September/October 2010 .

CHEIBUB, José Antonio; ELKINS, Zachary; GINSBURG, Tom. Latin American Presidentialism in Comparative and Historical Perspective. In: Public Law and Legal Theory Working Paper 361. Chicago: University of Chicago Law School, 2011.

COMMISSION OF THE EUROPEAN UNION. Communication from the Commission to the European Parliament and the Council on the Commission's objectives, in the framework of the relations between the European Union and Latin America, in view of the 3rd Summit of Heads of State and Government of the European Union and Latin America and the Caribbean to be held in Guadalajara (Mexico), on May 28th, 2004. Available at: <http://trade-info.cec.eu.int/doclib/docs/2004/april/tradoc_116662.pdf >. Accessed on: August 21st, 2013.

CRANDALL, Russell. The Post-American Hemisphere - Power and Politics in an Autonomous Latin America. Foreign Affairs, May/June 2011. 
DABÈNE, Olivier. The Politics of Regional Integration in Latin America Theoretical and Comparative Explorations. Basingstoke: Palgrave Macmillan, 2009.

DEL ARENAL, Celestino. Relations between the EU and Latin America: Abandoning Regionalism in Favor of a New Bilateral Strategy? In: Working Paper 36/2009. Madrid: Elcano Royal Institute, 2009.

DINAN, Desmond. Europe Recast - A History of European Union. Basingstoke: Palgrave Macmillan, 2004.

EUROPEAN UNION. EU-Latin America: 10 Years of Strategic Partnership. In: MEMO/09/426. Brussels: European Union, 2009.

FRERES, C.; SANAHUJA, J. A. Hacia una nueva estrategia en las relaciones Unión Europea-América Latina. In: (Coords.). América Latina y la Unión Europea. Estrategias para una asociación necesaria. Madrid: Icaria/Antrazy, 2006. p. 23-104.

GARDINI, Gian Luca. The EU-Latin American Summit: Strong Emphasis on Business Links. JLT World Risk Review 2013. Available at: $<$ http://blog.worldriskreview.com/2013/03/13/the-eu-latin-america-summitstrong-emphasis-on-business-links>. Accessed on: September 1st, 2013.

GOLDIROVA, Renata. The EU: A Model Impossible to Export? EU Observer, March 22nd 2007. Available at: <http://euobserver.com/news/23753>. Accessed on: August 30th, 2013.

LEHMANN, Kai. Mérito obscurecido. Ciência Hoje, v. 50, n. 299, 2012.p. 24.

Crisis, what crisis? The Overlapping Problems of the European Union. Revista de Sociologia e Política, [forthcoming].

LULA and his Squabbling Friends. The Economist, August 13rd, 2009.

MAIHOLD, Günther. Foreign Policy as Provocation: Rhetoric and Reality in Venezuela's External Relations under Hugo Chavez. In: SWP Research Paper 1. Berlin: Stiftung Wissenschaft und Politik, 2009.

MALAMUD, Andrés. Sovereignty Is Back, Integration Out: Latin American Travails with Regionalism. In: ROY, J. (Ed.). The State of the Union(s): The Eurozone Crisis, Comparative Regional Integration and the EU Model. Miami: University of Miami, Inter-American Jean Monnet Chair, 2012. 
The Crisis of the European Union and Its Impact on Regionalism in Latin America

. Overlapping Regionalism, No Integration: Conceptual Issues and the Latin American Experiences. In: EUI Working Paper RSCAS 2013/20. Florence: European University Institute, 2013.

; GARDINI, G. L. Has Regionalism Peaked? The Latin American Quagmire and Its Lessons. The International Spectator: Italian Journal of International Affairs, v. 47, n. 1, p. 116-133, 2012.

MANNERS, Ian. The Normative Ethics of the European Union. International Affairs, v. 84, n. 1, p. 65-80, 2008.

NOGUÉS, Julio J.; QUINTANILLA, Rosalinda. Latin America's Integration and the Multilateral Trading System. In: MELO, J. de; PANAGARIYA, A. (Ed.). New Dimensions in Regional Integration. Cambridge: Cambridge University Press, 1994.

NOW for the reckoning. The Economist, March 9th, 2013.

PARAGUAI: Mercosul quer entrada da Venezuela com armadilha. Exame, September 12th, 2012.

PHILLIPS, Nicola; PRIETO, German C. The Demise of New Regionalism. Reframing the Study of Contemporary Regional Integration in Latin America. In: PICARD, A. A.; RODRÍGUEZ, G.; BUSTAMENTE, N. C. The European Union: Promoter of Regional Integration in Latin America? Rhetoric and Reality. Amsterdam: Transnational Institute, 2011.

ROTHKOPF, David. Brazil's New Swagger. Foreign Policy, February 28th, 2012.

SARAIVA, Miriam G. Brazil's Strategic Partnerships: The Place of the European Union. In: Paper presented at the 2013 Congress of the Latin American Studies Association. Washington, D.C., May 29th-June 1st, 2013.

SECO, Miguel H. Decoupling Trade from Politics: The EU and Region-Building in the Andes. In: IAI Working Papers 11/20. Rome: Italian Institute of International Affairs, July 2011.

SHIFTER, Michael. The Shifting Landscape of Latin American Regionalism. In: Reckoning with Regions 4. Washington: Inter-American Dialogue, 2012. Available at: <http://www.thedialogue.org/page.cfm?pageID= 32\&pubID=2843>. Accessed on: March 15th, 2013. 
SMITH, Peter H. Talons of the Eagle: Latin America, the United States and the World. 3rd ed. Oxford: Oxford University Press, 2007.

RUIZ, Josè Briceño. The FTAA and the EU: Models for Latin American Integration? In: Jean Monnet/Robert Schuman Paper Series, v. 6, n. 2. Miami: University of Miami, 2006.

WILliamson, Edwin. The Penguin History of Latin America. London: Penguin, 2009.

\section{Abstract}

\section{The Crisis of the European Union and Its Impact on Regionalism in Latin America}

At the same time during which the European Union is passing through one of the worst crises in its history, the attempts to promote regionalism in South America are also beset by grave problems, with some commentators suggesting that 'regionalism is out, sovereignty back in', in the words of Andrés Malamud.

This article aims to respond to the question whether there is a connection between the problems confronted in Europe and the difficulties here in the region. In other words, what has been the impact of the European crisis on the prospects for highly developed regionalism in South America.

Based on interviews with policy-makers and representatives of Brazilian industry, as well as an analysis of the existing literature, the article argues that, even though both have suffered as a consequence of the general global political and economic trends - and both suffer from similar problems in terms of their strategic thinking - the particularities of each case does not allow for a direct causal link between the European and South American case.

Keywords: Regionalism - European Union - Latin America - Crisis 